\title{
Domestic servitude and ritual slavery in West Africa from a human rights perspective
}

\author{
Veronika Gyurácz* \\ Doctoral candidate, Corvinus University of Budapest, Hungary
}

\begin{abstract}
Summary
The article examines two examples of human rights violations, namely, domestic servitude and ritual slavery, which are considered forms of contemporary slavery, as they involve the exploitation of labour and the violation of the right to property. It is argued that the current international protection of children's rights is incapable of abolishing ritual slavery and domestic servitude in countries of West Africa, as children and teenagers are still threatened by the practice of vidomegon in Benin, trokosi in Ghana, and vudusi in Togo. The purpose of the article is to analyse West African forms of ritual slavery and domestic servitude and to demonstrate that the shortcomings of the international children's rights protection system emanate from the inconsistency of international and African perceptions of childhood. With this in mind, the focus is on the conceptual differences between the UN Convention on Children's Rights, the relevant ILO Conventions, the African Charter on the Rights and Welfare of the Child and the shortcomings in the definition of slavery in the Slavery Convention of 1926, as well as the Supplementary Convention on the Abolition of Slavery, the Slave Trade, and Institutions and Practices Similar to Slavery.
\end{abstract}

Key words: ritual slavery; domestic servitude; West Africa; children's rights; contemporary slavery; child labour

* MPhil (Corvinus, Budapest); veronika.gyuracz@hotmail.com 


\section{Introduction}

Human Rights Watch raised the alarm in 2015, claiming that ${ }^{1}$

children have been injured - and, in at least one case, killed - in mine collapses, and suffered from pain and respiratory problems caused by their work [in Ghana]. They also risk brain damage and other life-long disabilities from mercury poisoning. Most children who work in mining attend school, and some work specifically to cover school-related costs. However, many attend school irregularly or drop out.

Gold mining in Ghana is but one of the industries in West Africa, apart from the cocoa industry in Côte d'Ivoire, where children are forcibly employed. Furthermore, various religious practices in some West African countries use children, especially girls, in service as domestic servants or even as sex slaves. The current analysis regards child labour and ritual forms of labour exploitation of children as forms of contemporary slavery, as they amount to 'forced labour without payment' with 'the control without ownership; violence (or the threat of violence); coercion (loss of freedom and choice); and exploitation (of labour power through unpaid work)' ${ }^{2}$ In other words, the lack of payment and the violent control over the right to free movement of the person concerned distinguishes slavery from other forms of employment. In addition, contemporary forms of slavery, such as forced labour, child labour, domestic servitude, sexual slavery, debt bondage, forced marriage and human trafficking, have to be distinguished from traditional slavery of the period from the sixteenth to the nineteenth centuries, when slavery was practised around the world, and when the international human rights conventions in effect outlawing slavery did not exist. Furthermore, present-day slavery is not only in the obvious form where one person owns another person (traditionally called 'chattel slavery'). Slavery is illegal everywhere and, therefore, to perpetuate it, corruption and crime are involved. The power of the slave owner is always subject to the power of the state. Slavery can only continue to exist if governments permit this, and some writers claim that government corruption is a leading cause of the persistence of slavery. ${ }^{3}$

According to the statistics of the Australian Walk Free Foundation, 29,8 million people were considered to be victims of contemporary slavery worldwide in 2013, while this number increased to 35,8 million in 2014 , due to the more refined methodology of the

1 Human Rights Watch 'Ghana: Child labour taints gold supply chain' 10 June 2015, https://www.hrw.org/news/2015/06/10/ghana-child-labor-taints-gold-supplychain (accessed 8 March 2015).

2 K Manzo 'Modern slavery, global capitalism and deproletarianisation in West Africa' (2005) 106 Review of African Political Economy 522.

3 'Modern slavery' http://www.bbc.co.uk/ethics/slavery/modern/modern_1.shtml (accessed 29 April 2017). 
research into slavery. ${ }^{4}$ In 2015, 45,8 million people were reported to be victims of some form of modern slavery. ${ }^{5}$ According to the Walk Free Foundation, modern slavery means 'human trafficking, forced labour, debt bondage, servile marriage, and the sale and exploitation of children'. ${ }^{6}$ With this number, the Walk Free Foundation eclipsed the 2012 data of the International Labour Organisation (ILO) about people suffering from forced labour. According to the ILO, 20,9 million people were forced to work under violent circumstances. ${ }^{7}$ This data again confirms the worldwide existence of contemporary slavery of which forced labour is one type. The victim is threatened with punishment and his or her rights to work and to free movement are violated.

Despite the high number of victims, there still is no unanimous agreement among the international community about a definition of slavery. However, it is necessary to arrive at a definition in order to prohibit the trade in slaves and human trafficking. Slavery is a ius cogens norm in international law and the prohibition upon slavery applies unconditionally.

Nevertheless, a few practices confirm the existence of contemporary slavery, for instance those in West Africa. There, the international protection of children's rights fails as ritual slavery and domestic servitude occur. The survival of exploitative domestic and religious practices is proof that international human rights law has as yet been unable to put the relevant conventions into practice. Despite the fact that every country in Africa has ratified the Convention on the Rights of the Child (CRC), and 41 out of the 54 African countries have signed and ratified the African Charter on the Rights and Welfare of the Child (African Children's Charter), illegal practices that deprive children of their rights to liberty and education are rife in certain parts of Africa. ${ }^{8}$ The article examines three forms of regional human rights violations, namely, vidomegon in Benin, trokosi in Ghana, and vudusi in Togo, and considers them forms of contemporary slavery due to their exploitative character. The author argues that as children and teenagers are still victims of these exploitative practices, it is evident that the current international protection fails to protect children's rights in West Africa.

Two obstacles to the abolition of the illegal practices in the region are identified. The international child protection systems aimed at the abolition of ritual slavery and domestic servitude are full of

4 Walk Free Foundation 'The global slavery index 2014' http://d3mj66ag90b5fy. cloudfront.net/wp-content/uploads/2014/11/Global_Slavery_Index_2014_final_ lowres.pdf (accessed 25 March 2015).

5 Walk Free Foundation 'The global slavery index 2015' http://assets.globalslavery index.org/downloads/Global+Slavery+Index+2016.pdf (accessed 25 June 2016).

6 Global slavery index 2015 ( 5 above) 12.

7 ILO Global estimate of forced labour (2012) 13.

8 African Commission on Human and Peoples' Rights Ratification table: African Charter on the Rights and Welfare of the Child (2015). 
shortcomings. On the one hand, the international normative framework of children's rights is insufficient, as it does not effectively recognise the regional differences of the role of the child in society. On the other, the international human rights instruments addressing the abolition of forms of contemporary slavery are continuously suffering from the problems of national implementation. However, the article does take into consideration the fact that the survival of contemporary slavery practices can be explained by economic necessity, poverty, and economic inequality in the region. However, since vidomegon, trokosi and vudusi affect mainly children in a few countries of West Africa, the article argues that inconsistencies in the international and regional perceptions of children's rights thwart the abolition of slavery in contemporary West Africa.

\section{Domestic servitude and ritual slavery in Benin, Ghana and Togo}

The situation of children in West Africa does not conform to the environment required by international human rights instruments. Ike and Twumasi-Ankrah describe childhood in West African countries as riddled with 'poverty, malnutrition, child labour, rural-urban migration, ignorance and lack of education, parental lack of financial support and maintenance of children'. ${ }^{9}$ Furthermore, in 2007 the Global Fund of Children claimed that ${ }^{10}$

children in West Africa are more likely to be raped, trafficked, beaten or abused and are less likely to go to school or receive proper health care or be properly nourished compared with fifteen years ago, despite binding legislations meant to improve children's situation.

Because of these unfavourable circumstances, domestic servitude and ritual slavery are deeply rooted in a few West African societies and are systemic forms in African traditional religions. The vicious cycle of poverty, technological underdevelopment and rising demand for unskilled workers is confirmed by the existence of vidomegon (translated as 'placed children' in Fon, the main spoken language of the country) in the commercial centres of Benin which are the breeding grounds of child labour for children of the ages of five to 14 years. ${ }^{11}$ Vidomegon constitutes a real problem in Beninese society, decades after the country's independence: According to 2008 data from the United Nations Children's Fund (UNICEF), around 500000 children, mainly girls, work as slaves of the merchants of the big

9 M Soussou \& J Yogtiba 'Abuse of children in West Africa: Implications for social work education and practice' (2009) 39 British Journal of Social Work 1219.

10 As above.

11 UNICEF 'Benin factsheet 2008. Note de briefing sur le programme protection' (2008) http://www.unicef.org/wcaro/WCARO_Benin_Factsheet_Protection-fr-Nov07.pdf (accessed 27 February 2015). 
markets. ${ }^{12}$ However, Benin referred to the issue of vidomegon in 2013 to the United Nations (UN) Committee on the Elimination of Discrimination against Women, as a past threat against human rights in the country and as an already-prohibited activity. In their reply to the concerns of the Committee, they stated that it was a cultural tradition; when parents could not afford to send their children to school, they sent them away to receive an education and care by a wealthier family' ${ }^{13}$ The country proudly announced that ${ }^{14}$

considerable work was being done to prevent children from being kept in domestic servitude. The issue had been publicised on television, and people who tried to sell their children at markets were arrested, and their children were sent to school.

Although the authorities in Benin consider vidomegon as an alreadyabolished form of servitude, local non-governmental organisations (NGOs) continue to claim that children are transferred by trafficking networks between West and Central African countries. ${ }^{15}$ Morganti emphasises that the term vidomegon was used in the beginning to refer to domestic servants in the revolutionary period (1972-1989). She describes the phenomenon as follows: ${ }^{16}$

People of the countryside started to place their children in urban households in order to get back a sum for the children's work. Originally, the aim of vidomegon was a good practice for girls to learn about the housework. But as soon as the guardian starts to maltreat the child by giving him or her instructions in exchange of accommodation and nutrition, this is the point when vidomegon is born in its current sense. The child is not there to learn anymore, but to serve.

The recruitment of girls for commercial tasks and domestic housework has accelerated in West Africa in the past three decades. Although it seems to be beneficial for traffickers and urban households, it is considered illegal according to article 3 of the UN Protocol to Prevent, Suppress and Punish Trafficking in Persons Especially Women and Children. ${ }^{17}$ In Benin, it is mainly in Cotonou, the administrative capital, where the demand for child labour is high. ${ }^{18}$ Merchants employ children to sell their products in the city's biggest markets or force them to do domestic work. Furthermore, children regularly

12 As above.

13 Office of the United Nations High Commissioner for Human Rights (OHCHR) 'Committee on the Elimination of Discrimination against Women considers report of Benin' (2013) (accessed 20 January 2016).

14 As above.

15 S Morganti 'À l'écoute des victimes: Les défis de la protection des vidomègon au Bénin' (2014) 4 Autrepart 78.

16 Morganti (n 15 above) 81.

17 The recruitment, transportation, transfer, harbouring or receipt of a child for the purpose of exploitation shall be considered 'trafficking in persons' (UN Protocol to Prevent, Suppress and Punish Trafficking in Persons Especially Women and Children, supplementing the United Nations Convention against Transnational Organised Crime, General Assembly Resolution 55/25 of 15 November 2000).

18 M Boni Teiga 'Vidomegon, les enfants-esclaves du Benin' (2011) http://www. slate afrique.com/731/vidomegon-enfants-esclaves-benin (accessed 27 February 2015). 
suffer physical abuse by their 'masters' when they make any mistakes in their work. ${ }^{19}$

The high demand for labour in Benin is met by a large number of children sent from other West and Central African countries that, at the same time, accept children from Benin for labour. Children from Equatorial Guinea, Cameroon, Gabon, the Democratic Republic of the Congo and Côte d'Ivoire all are involved in the regional network of human trafficking that provide children for the domestic market. The international media started dealing with child labour when the ship, Etinero, limped into the port of Cotonou in Benin on 17 April 2001. Investigations revealed that the children who left the ferry after three weeks at sea had been destined to join the 200000 children sold every year in Africa's modern slave trade. ${ }^{20}$ The children were supposed to work as housemaids for their masters in Gabon who had bought them from the traffickers. ${ }^{21}$ The case of the Etinero illustrates the cruel reality of domestic servitude in West Africa. Children are sold and resold, sometimes until they have grown up. They are deprived of the right to live in a family, to live as a child and to go to school. They are not aware of their rights and the possibilities that could help them avoid being trapped in labour. They forget their parents and, as they get into domestic servitude at an early age, even their language. According to UNICEF, the situation seems to have become very serious. In 2014, UNICEF stated that through flourishing trafficking, 200000 children are trafficked annually in West Africa alone, and are then forced into domestic or ritual servitude. ${ }^{22}$ However, available data about the number of victims is contested between the various parties involved. Governments tend to give lower numbers, while NGOs and the media usually report higher numbers in order to draw attention to the problem. Therefore, research can rely only on the estimation of UNICEF which gauges that worldwide 150 million children were routinely engaged in paid or unpaid forms of work during the period 2001 to $2014,{ }^{23}$ and that 25 per cent of these children worked in sub-Saharan Africa, the highest average among the regions. ${ }^{24}$ This means that around 38 million children are vulnerable to forced labour and to physical and mental exploitation in subSaharan Africa. ${ }^{25}$ Sawadogo is of the opinion that these numbers are the consequence of the structural difficulties of West African

19 As above.

20 'The slave children' (2001) http://news.bbc.co.uk/2/hi/programmes/correspon dent/1519144.stm (accessed 10 March 2015).

21 As above.

22 UNICEF 'An estimated 150 million children worldwide are engaged in child labour' (November 2014), http://data.unicef.org/child-protection/child-labour\#st hash.k3HKz6pm.dpuf (accessed 24 March 2015).

23 As above.

24 As above.

25 As above. 
economies. He examines the widespread network of forced child labour in West African countries by claiming that ${ }^{26}$

[t]he fast growth of West African populations, the uncontrolled urbanisation in the region, poor security, and economic hardships associated with wide inequalities in the distribution of wealth, contribute to an increased salience of human trafficking as an available option, to break out of poverty.

Human trafficking networks active among West and Central African countries are the main organisers of child labour. Child labour and servitude often seem to be logical alternatives for children, as parents argue that national governments are not able to provide the minimum conditions for education. Due to a lack of schools and no functional education system, families in West Africa claim that they would prefer sending their children to earn money for the family instead of sending them to school where they would only waste their time. Unfortunately, children are in a disadvantaged position, if one considers that, according to Vernor Muñoz Villalobos, the Special Rapporteur on the Right to Education from 2004 to 2010,27

[a]lthough a good number of African countries have nominally provided for the right to free and compulsory primary education, only [two] African countries $^{28}$ could be declared, in 2006 , to provide a 'proper' free and compulsory primary education.

For governments that have signed and ratified the CRC, it is an obligation to provide education under healthy and stable conditions. If education is not accessible to children, they lose the most basic opportunity to be rescued from the exploitative practices that still exist in their countries. Having acknowledged these dangers, the UN included universal primary education in the Millennium Development Goals (MDGs) that were supposed to have been reached by 2015. This is one of the most crucial development areas in the field that is able to contribute to the abolition of contemporary slavery.

Despite the fact that domestic servitude is widespread in Benin, there have been initiatives in the country to outlaw these systematic human rights violations. Therefore, it cannot be said that Benin did not intend to execute its duties related to the CRC or the African Children's Charter. According to article 7 of the 2006-04 Law, ${ }^{29}$

26 W Sawadogo 'The challenges of transnational human trafficking in West Africa' (2012) 13 African Studies Quarterly 96.

27 J Sloth-Nielsen \& B Mezmur 'Surveying the research landscape to promote children's legal rights in an African context' (2007) 7 African Human Rights Law Journal 343.

28 Madagascar and Mauritius.

29 Benin Parliament 'La loi 2006-04 du 10 avril 2006 portant conditions de déplacement des mineurs 2006-04' http://www.nouvellesmutations.com/2007/ 11/06/loi-n\%C2\%B02006-04-du-05-avril-2006-portant-conditions-de-deplace ment-des-mineurs-et-repression-de-la-traite-des-enfants-en-republique-du-benin/ (accessed 12 August 2015). 
[n]o child can be moved out from his or her country of birth and be separated from his or her biological parents or from the person having authority over him or her without the special permit from the competent administrative authority of his place of residence except judicial decisions or matters especially recommended by the social and health services.

Article 4 of the 2006-04 Law clarifies what Beninese law makers understand to be exploitation, emphasising that the practice of domestic servitude and other forms of forced employment are illegal. According to Law 2006-04, 30

exploitation means ... all forms of slavery and similar practices, debt bondage and serfdom, and forced or compulsory labour, using children in armed conflicts or for the removal of organs, using or offering children for prostitution the production of pornographic works or for pornographic performances, using or offering children for illicit activities, the works that by their nature and/or their conditions in which they are carried out, are likely to harm the health, the security and the morality of the child or to release himself or herself.

Even though Beninese legislation prohibits a wide list of practices, including the still-flourishing vidomegon, the government does not acknowledge the existence of contemporary slavery in the country. Despite being a signatory to the CRC and the main international human rights instruments that proscribe contemporary slavery, ${ }^{31}$ Benin has yet to ratify the 1956 Supplementary Convention on the Abolition of Slavery, the Slave Trade, and Institutions and Practices Similar to Slavery. Even though Benin was the first African country to pass an anti-human trafficking Bill in 1961, because of the lack of financial backing to implement the anti-slavery efforts, the government's willingness to establish national legal frameworks that outlaw domestic servitude and other forms of contemporary slavery is highly questionable.

In Ghana, the practice of trokosi provides an example of ritual slavery. According to this practice, virgin girls are given to southeastern village priests as a way of appeasing the gods for crimes committed by family members. ${ }^{32}$ According to the ideology of trokosi, 'once given to the priest, a girl becomes his property and is forced to carry out domestic tasks such as cooking and washing, as well as farming and fetching water'. After the onset of menstruation, the bondage also involves sexual servitude. ${ }^{33}$ The practice of trokosi is still flourishing in the rural areas of Ghana, despite the amendment of the

30 As above.

31 Benin ratified the 1926 Slavery Convention and its Protocol of 1953 in 1962 and also ratified the ILO 182th Convention on the Worst Forms of Child Labour in 2001.

32 V Mistiaen 'Virgin wives of the fetish gods - Ghana's trokosi tradition' (2013) http://news.trust.org//item/20131003122159-3cmei/ (accessed 13 January 2016).

33 N Ben-Ari 'Liberating girls from trokosi in Ghana' (2001) UN Africa Recovery http:// www.un.org/en/africarenewal/subjindx/childpdf/childgha.pdf (accessed 20 March 2015). 
Ghanaian Criminal Code in 1998 to protect the victims of ritual slavery. ${ }^{34}$ However, since then no priest has been sentenced to imprisonment. ${ }^{35}$ Trokosi, a classical example of ritual slavery, is ${ }^{36}$

a tradition [that is also] practiced in neighbouring Benin and Togo, [and] is deeply rooted in the beliefs and identity of the Ewe (ay-vay) people. It serves rural communities' need for justice and meets the material and sexual needs of the fetish priests. But it is also considered a spiritual act and as such it is, along with female genital mutilation, one of the most difficult human rights violations to eradicate.

Although trokosi occurs in Benin and Togo, most of the information about this practice emanates from Ghanaian NGOs such as International Needs Ghana, the latter being central to the release and rehabilitation of victims of trokosi. ${ }^{37}$ It negotiates the return of these women and girls to their families or communities, provides housing, food, counselling, schooling and courses on income-generating skills. Survivors for Change, a human rights organisation formed by survivors of trokosi, also advocates law enforcement measures against the practice, and launched its own campaign to seek support from various government ministries and international ambassadors based in Accra. ${ }^{38}$ The organisation Equality Now, which has focused on discrimination, sexual violence, trafficking and female genital mutation since 1992, is deeply concerned that, after a few years of judicial prohibition of trokosi, several thousands of girls and women are reported to still be in ritual servitude. ${ }^{39}$ Unfortunately, the illegality of trokosi is not evident in the West African countries concerned as, on the one hand, there is a crucial lack of reliable data due to the underground and illegal nature of ritual slavery. On the other hand, as some traditionalist groups in Ghana argue, the practice is part of culture and, therefore, the law should not destroy it. ${ }^{40}$ For instance, representatives of the Afrikania Mission ${ }^{41}$ are said to be

34 B Nicholas 'Legal immanence: religion, mythology, and the influence of the divine' (2011) 8 US-China Law Review 483.

35 Mistiaen (n 32 above).

36 As above.

37 S Aird 'Ghana's slaves to the gods' (2000) https://www.wcl.american.edu/hrbrief/ v7i1/ghana.htm_(accessed 25 March 2015).

38 'Slavery in Ghana: The trokosi tradition' (2002) http://www.equalitynow.org/ node/185 (accessed 23 March 2015).

39 As above.

40 'Afrikania Mission straightens record on trokosi' (2012) http://www.modern ghana.com/news/398477/1/afrikania-mission-straightens-record-on-trokosi.html (accessed 20 March 2015).

41 Afrikania Mission is a neo-traditional movement established in Ghana in 1982 by a former Catholic priest, Kwabena Damuah, who resigned from the church and assumed the traditional priesthood titles Osofo Okomfo. The Mission aims to reform and update African traditional religion, and to promote nationalism and pan-Africanism. Rather than being a single new religious movement, Afrikania also organises various traditional shrines and traditional healers into associations, bringing unity to a diffused system and thereby a greater voice in the public arena (for further details, see http://what-when-how.com/religious-movements/ afrikania-mission-religious-movement/). 
exerting pressure to prevent the enforcement of the law, and to have persuaded some priests that it is their right to continue the tradition. ${ }^{42}$ They deny the existence of ritual slavery within the religion by claiming that the report of International Needs Ghana contains false information about African traditional religion. ${ }^{43}$ Defending allegations of ritual slavery in shrines, the Afrikania Mission refers to its own report stating that the trokosi shrine system does not exist in Ghana. ${ }^{44}$ Nevertheless, they confirm that the so-called trokosi shrines 'were a complex of many institutions including healing centres, pharmacies, places of devotional service, refuge sanctuaries, schools, conservatories of culture and morality, lodges of esoteric knowledge and courts for the administration of justice' ${ }^{45}$ The two practices are so closely related that they require follow-up by national and international human rights organisations in order to avoid an increase in the number of victims of contemporary slavery.

Claims of NGOs about the existence of ritual slavery in Ghana are also regularly reviewed by the US State Department, which states that trokosi is a religious practice 'involving a period of servitude lasting up to 3 years'. ${ }^{46}$ However, trokosi is mentioned neither in the 2014 nor in the 2015 Trafficking in Persons (TIP) report, as among human trafficking-related human rights violations in Ghana. The US Secretary of State makes the reasonably generic observation that ${ }^{47}$

Ghanaian boys and girls are subjected to forced labour within the country in fishing, domestic service, street hawking, begging, portering, artisanal gold mining, and agriculture. Ghanaian girls, and to a lesser extent boys, are subjected to prostitution within Ghana. Child prostitution is prevalent in the Volta region and is growing in the oil-producing western regions.

However, the exploitation of children within the religious framework of trokosi has not been confirmed by the US Secretary of State.

Nevertheless, NGOs are still gathering information from victims about alleged sexual exploitation in the form of ritual slavery. Within the framework of trokosi, the religious context persuades parents that it is their duty to the priests to send their children to live and work for the shrines. The fact that awareness about trokosi is more widespread among national NGOs than the US authorities illustrates that, although ritual slavery has for decades been present in Ghanaian society, it has been hidden from the authorities because of its clandestine and ambiguous religious background. Due to general corruption and bribery in the judicial system, and the denial of traditional religious groups, victims of ritual slavery in Ghana do not

42 Afrikania Mission (n 42 above).

43 As above.

44 As above.

45 As above.

46 United States Department of State 'Trafficking in persons report' (2014) 185 http:// www.state.gov/documents/organization/226846.pdf (accessed 25 March 2015).

United States Department of State (n 48 above) 186. 
receive the required attention from national human rights mechanisms. ${ }^{48}$ The US Department of Labor, for example, evaluated the efforts of Ghana in abolishing the worst forms of child labour in 2015 as moderate. Although Ghana aimed to eliminate the worst forms of child labour in West Africa by 2015 through the implementation of a regional action plan with 14 other Economic Community of West African States (ECOWAS) countries, it did not participate in any activities under this policy in $2015 .^{49}$ The national human rights mechanism has also been weakened by the fact that the government has not ratified the UN CRC Optional Protocol on the Sale of Children, Child Prostitution and Child Pornography. Additionally, the US Department of Labor emphasises that ${ }^{50}$

[r]esource constraints severely limited the government's ability to fully implement policies and social programs during the reporting period. The government of Ghana also has not provided any funding for anti-trafficking enforcement efforts or programs to protect victims of human trafficking.

These efforts are necessary as trokosi violates article 14 of the Ghanaian Constitution, which states that '[e]very person shall be entitled to his personal liberty and no person shall be deprived of [it]' ${ }^{51}$ Moreover, article 16 provides that '[n]o person shall be held in slavery or servitude [and] no person shall be required to perform forced labour', repeating the principles of the Slavery Convention of 1926 and the Supplementary Convention on the Abolition of Slavery, the Slave Trade, and Institutions and Practices Similar to Slavery of 1956. ${ }^{52}$ Even though Ghana has adopted the required legal instruments against slavery and child labour, thanks to the 1992 Constitution, the Child's Act 560 of 1998 and the Labour Act 651 of 2003, not one person has yet been prosecuted for ritual servitude. ${ }^{53}$

In addition, vudusi, a type of voodoo practice through spiritual entities, is widespread in neighbouring Togo. According to Walk Free Foundation's Global Slavery Index published in 2013, 54

48 A Laing 'Ghana suspends seven High Court judges over bribe-taking film' The Telegraph 6 October 2015, http://www.telegraph.co.uk/news/worldnews/africaan dindianocean/ghana/11915763/Ghana-suspends-seven-high-court-judges-overbribe-taking-film.html (accessed 3 April 2016).

49 United States Department of Labor 'Findings on the Worst Forms of Child Labor' https://www.dol.gov/sites/default/files/images/ilab/child-labor/Ghana.pdf (accessed 4 June 2017) 6.

50 As above.

51 Constitution of Ghana (1992) http://www.ghanaweb.com/GhanaHomePage/ republic/ constitution.php (accessed 15 September 2016).

52 As above.

53 UN Special Rapporteur on Violence against Women 'Ghana - trokosi - Ritual servitude and sexual abuse' (2008) http://www.wunrn.com/news/2008/03_08/ 03_17_08/031708_ghana.htm (accessed 18 August 2015).

54 Walk Free Foundation 'Global slavery index 2013' (2013) 59 http://d3mj66ag9 0b5fy.cloudfront.net/wp-content/uploads/2014/11/2013GlobalSlaverylndex.pdf (accessed 15 March 2015). 
[w] here voodoo is practised, a lot of children, mainly virgin girls, are given to the voodoo idol gods. The children have no word or choice in being given into the practice by their parents or by other family members, and they are horrified at the duties they are forced to perform for these 'gods'.

Therefore, the girls who become victims of vudusi become the wives or slaves of the 'voodoo gods'. They may be considered victims of contemporary slavery as their right to free movement is violated and they are exploited economically and sexually. No attempt has so far been made to survey the number of children that in reality are affected by vudusi in Togo. ${ }^{55}$ Therefore, the limited information about the extension of ritual slavery in Togo comes from victims of shrine slavery after they have been freed, and it is almost impossible to obtain preliminary interviews while the children are still under the influence of and subject to the order of the shrines. ${ }^{56}$ Due to this clandestine feature, providing protection to children in Togo is difficult as neither regional nor international organisations have a clear picture of exactly how many children are influenced by ritual slavery in the country. The initiatives of Every Child Ministers (ECM), a Christian anti-slavery group, are exceptions, as they conducted an investigatory mission in 2005 in Togo to see how many victims should be helped. Based on the conclusion of this investigation, ECM launched a teacher-training and awareness-raising programme in 2007 about vudusi. ${ }^{57}$ The struggles of ECM indicate a lack of information available to national decision makers, convincing them that the spectrum of the problem is no longer widespread. As a consequence, there is a decline in attention paid to the problem by Togolese authorities. In Togo, similar to the situation in Ghana and Benin, there is an apparent lack of governmental commitment to investigation, resource allocation, enforcement of laws, and the development of comprehensive awareness raising, child protection and family welfare programmes. Therefore, the existence of domestic servitude and ritual slavery leads to an endangered psycho-social development of children in the sub-region due to unfavourable economic and social conditions. Consequently, as is outlined below inconsistencies in the understanding of human rights are not the sole reason for ongoing exploitation, but represent serious challenges to the international protection of children's rights, and cause problems in the implementation on the ground of international human rights instruments. These dysfunctionalities are further intensified by poverty and economic inequalities in the micro-environment of potential victims.

57 'Freeing vudusi - Children given to voodoo idol gods' http://www.ecmafrica.org/ projects/find-project-by-topic/ritual-slavery--abuse/vudusi-slave-children-in-togo (accessed 20 January 2016). 


\section{Lack of international agreement about contemporary forms of human rights violations}

The occurrence of vidomegon in Benin, trokosi in Ghana and vudusi in Togo confirm that children are still being threatened by domestic servitude and ritual slavery in some countries of West Africa, despite the fact that the special needs of children have been the priority of the international and regional protection of human rights since the foundation of the UN and the African Union (AU). ${ }^{58}$ As a consequence, it is crucial to understand that domestic servitude and ritual slavery are forms of contemporary slavery since their victims are exploited by the practices. The prohibition of slavery, child labour, forced labour and human trafficking has been the focus of the UN legal framework since its foundation. The international conventions of the UN and the International Labour Organisation (ILO) provide the normative dimension for the protection of the rights of the victims, demanding local authorities to abolish the still-existing regional forms of human rights violations.

First and foremost, international law forbids domestic servitude and ritual slavery. ${ }^{59}$ As forms of slavery, their prohibition belongs to the category of ius cogens norms in international law, meaning that this principle has to be applied unconditionally regardless of the fact that countries have ratified the relevant conventions. ${ }^{60}$ However, the adoption and implementation of abolition programmes are hindered by the fact that neither in international law nor in academic discourse is there consensus about which practices should be considered slavery. Those advocating the protection of human rights cannot even agree on the difference between traditional and contemporary slavery. As a consequence, we cannot expect there to be structured systems of protection in the region concerned when even the UN incorporates human trafficking completely into the definition of slavery. Furthermore, several governments conflate human smuggling with human trafficking as two equivalent phenomena on the level of policy-making and official communication. ${ }^{61}$

58 The Organisation of African Unity, the predecessor of the African Union, adopted the African Charter on the Rights and Welfare of the Child in 1990 and in 2003 it added the Protocol to the African Charter on Human and Peoples' Rights on the Rights of Women in Africa.

59 United Nations 'Report of the Temporary Slavery Commission to the Council of the League of Nations' (A.17.1924.VI.B) quoted in 'The suppression of slavery' Memorandum submitted by the Secretary-General to the Ad Hoc Committee on Slavery, United Nations document ST/SPA/4 (1951) para 22.

60 D Weissbrodt 'Abolishing slavery and its contemporary forms' (2002) 3 http:// www.ohchr.org/Documents/Publications/slaveryen.pdf (accessed 29 April 2017).

61 R Weitzer 'Human trafficking and contemporary slavery' (2015) 41 Annual Review of Sociology 225. 
The Victims of Trafficking and Violence Protection Act (TVPA), adopted in 2000 in the United States, can be considered an exception since it clearly states that ${ }^{62}$

[t]rafficking in persons is a modern form of slavery, and it is the largest manifestation of slavery today. At least 700000 persons annually, primarily women and children, are trafficked within or across international borders.

According to the definition in the TVPA, human trafficking ${ }^{63}$ is $^{64}$

the recruitment, harbouring, transportation, provision, or obtaining of a person for labour or services, through the use of force, fraud, or coercion for the purpose of subjection to involuntary servitude, peonage, debt bondage, or slavery.

Being the highest normative instrument to condemn human trafficking, the UN Protocol to Prevent, Suppress and Punish Trafficking in Persons, Especially Women and Children, supplementing the UN Convention against Transnational Organised Crime (Palermo Protocol) also concentrates on the elements of deception and force when defining human trafficking. However, it completes the definition with reference to the vulnerability of the victim, the abuse of power, and the enforcement of control over the individual to the point of exploitation. ${ }^{65}$ However, Weitzer exhorts that, although the Palermo Protocol may be regarded as a milestone in the fight against contemporary forms of systematic human rights violations, it lacks the definition of what is meant by exploitation, abuse of power, vulnerability and even control. ${ }^{66}$ Because of this defective notion, the Protocol cannot be applied successfully to concrete cases. Alternative indicators, such as violence, fraud or force, enable a more concrete measurement of human trafficking, as it would bring the specific cases closer to the definition in the legal instrument. ${ }^{67}$

62 United States Department of State 'Victims of Trafficking and Violence Protection Act 2000' http://www.state.gov/documents/organization/10492.pdf (accessed 15 September 2016) sec $102 / \mathrm{b} / 1$.

63 It is important not to confuse human trafficking with human smuggling, since the victims of human trafficking, considered a form of contemporary slavery, start the journey as a consequence of violence, force, threat or attractive promises. On the other hand, in the case of human smuggling the travellers themselves pay the fee of the trip to the smuggler. Human smuggling is an illegal, criminal act that cannot be considered slavery due to the lack of the practice of property rights, force and the exploitation of labour.

64 United States Department of State (n 62 above) sec 103/8.

65 United Nations Protocol to Prevent, Suppress, and Punish Trafficking in Persons, Especially Women and Children, supplementing the United Nations Convention against Transnational Organized Crime (2000) https://treaties.un.org/Pages/ ViewDetails.aspx?src=IND\&mtdsg_no=XVIII-12-a\&chapter=18\&lang=en (accessed 9 June 2016).

66 Weitzer (n 61 above) 225.

67 Weitzer 226. 
According to Rassam, the Palermo Protocol complements but does not supersede the already-existing international conventions on the 'white commerce of slavery'. ${ }^{68}$ Although the Protocol provides a more layered definition of human trafficking that includes forced prostitution, slavery and forced labour, Rassam warns that it only had the potential of breaking with the tradition of earlier conventions, and demands that states make greater efforts in the protection of trafficked people. ${ }^{69}$

Human trafficking provides connections to other forms of exploitation: It has close links to both domestic servitude and ritual slavery, since trafficked victims can easily end up as servants in another country. However, it is still important to clarify whether moving a victim from one place to another should be a crucial element in the crime of human trafficking. If the answer is in the affirmative, local forms of contemporary slavery such as domestic servitude, debt bondage and ritual slavery, would fall outside of the scope of international law offering protection from human trafficking. Unfortunately, both the Palermo Protocol and the TVPA leave the geographical movement of the victim out of consideration and they exclusively accentuate the recruitment, acceptance and hiding of the individual when defining human trafficking.

Inconsistencies in the protection available to victims further deepen when considering that neither the TVPA of the United States nor the Palermo Protocol deals with contemporary slavery as an individual human rights violation. Both documents primarily stress the protection of those victims that have been transferred over national borders, and do not deal with local forms of exploitation, such as the various forms of child labour. Although slavery is mentioned in these two legal documents, no mention is made of the fact that new forms of contemporary slavery, including domestic servitude or ritual slavery, should be regarded and dealt with as individual infringements. Even though the efforts of the UN Special Rapporteur on Contemporary Slavery have contributed to the abolition of contemporary slavery, this has not been enough to cause the UN to adopt an international human rights instrument that acknowledges the need for protection against contemporary forms of slavery.

International law still considers the Slavery Convention of 1926 as the main definition to be used for contemporary infringements. The Convention describes slavery as the practice of property rights, as it states that 'slavery is the status or condition of a person over whom

68 Y Rassam 'International law and contemporary forms of slavery: An economic and social rights-based approach' (2003) 23 Penn State International Law Review 812. 
any or all of the powers attaching to the right of ownership are exercised'. ${ }^{70}$ Thus, $^{71}$

[h]istorical and modern slavery are connected by the condition where more people practise authority over another person, the victim ... like an object or a property, restrict his or her movement, humiliate his or her human dignity, exploit him or her through manipulation and/or threat and/or mental and physical abuse.

The definition of slavery was expanded by the General Assembly of the UN in 1956 when the Supplementary Convention on the Abolition of Slavery, the Slave Trade and Institutions and Practices Similar to Slavery was attached to the Slavery Convention of 1926. Here, debt bondage and serfdom were added to the notion of slavery and the modern forms of slavery were regarded more broadly. The Convention referred to the most vulnerable victims, namely, women and children, by mentioning sexual exploitation, forced marriage and child labour. ${ }^{2}$

Bales and Robbins emphasise the ius cogens power of the prohibition of slavery in connection with the significance of the Supplementary Convention of 1956 . They argue that, since the fight against slavery has become one of the crucial tasks of the UN, it has to be regarded as a ius cogens norm. Therefore, the rights to a life, and freedom from slavery, have to be considered absolute norms by international law, and slavery is a crime against humanity under the jurisdiction of the International Court of Justice. Irrespective of whether a country has ratified the international conventions dealing with slavery, it has to be considered an international crime. ${ }^{73}$ Obviously, humiliation is a permanent feature of contemporary slavery. However, this concept is still void, as it does not permit a clear understanding of contemporary, diverse forms of human rights violations. It only emphasises the practice of property rights, mental and/or physical abuse and control.

As far as contemporary slavery is concerned, its definition has to be extended to include forced, arbitrary abuse of the victim's labour. This applies to forced labour, child labour, domestic servitude, ritual slavery, sexual slavery and debt bondage. This approach was adopted in a regional court case in 2008 when the ECOWAS Community Court of Justice ruled that slavery did not exist only where there is 'power of ownership', but may include other forms of control. In the judgment

70 OHCHR Slavery Convention (1926) http://www.ohchr.org/EN/Professional Interest/ Pages/SlaveryConvention.aspx (accessed 6 April 2016) art 1.

71 V Mihalkó et al Modernkori rabszolgaság képzési kézikönyv (Contemporary slavery handbook) 43.

72 United Nations 'Supplementary Convention on the Abolition of Slavery, the Slave Trade, and Institutions and Practices Similar to Slavery' (1956) http://www.ohchr. org/EN/Professionallnterest/Pages/SupplementaryConventionAbolitionOfSlavery. aspx (accessed 28 April 2017) art 1.

73 K Bales \& PT Robbins 'No one shall be held in slavery or servitude: A critical analysis of international slavery conventions' (2001) 2 Human Rights Review 22. 
of Hadijatou Mani Koraou $v$ The Republic of Niger, ${ }^{74}$ the Court condemned the Republic of Niger for a violation of articles 1, 2, 3, 5, 6 and 18(3) of the African Charter on Human and Peoples' Rights (African Charter). In this case the victim suffered not only from being the property of his or her master, but also from sexual and labour exploitation, including domestic servitude. ${ }^{75}$ While this case partly confirms the existence of slavery in certain countries of Africa, it also emphasises the need for a well-defined concept of slavery that respects its contemporary context. For instance, the autocratic disposal of the labour force distinguishes the practices belonging to contemporary slavery from other forms of exploitation, such as organ trafficking or prostitution.

\section{Inconsistency in international law and the regional interpretation of children's rights}

The protection of children from domestic servitude and ritual slavery has been guaranteed in the human rights framework since 1989 when the CRC was adopted by the UN. Manzo states that this type of protection mechanism 'universalised a Western model of childhood with an 18-year time period characterised by school, play and freedom from responsibility'. ${ }^{76}$ The Convention emphasised that children would need special attention in the field of education and health. Even though this protection was to be universal, Manzo argued that it included controversies about the image of protection guaranteed for children. Nhenga-Chakarisa emphasises that it renewed our understanding of the concept of child labour, although it did not define the term. He argues that '[a]lthough CRC was not the first UN Convention to provide for child labour it enlarged the scope of the prohibition of economic exploitation'. ${ }^{77}$ The enlarged scope appeared in the recognition of ${ }^{78}$

the right of the child to be protected from economic exploitation and from performing any work that is likely to be hazardous or to interfere with the child's education, or to be harmful to the child's health or physical, mental, spiritual, moral or social development.

74 (2008) ECOWAS Court of Justice $4 \mathrm{https://www.unodc.org/res/cld/case-law-doc/}$ traffickingpersonscrimetype/ner/2008/h_m_v_republic_of_niger_html/Hadijatou _Mani_v._Republic_of_Niger_Community_Court_of_Justice_Unofficial_English_tra nslation.pdf (accessed 27 April 2017).

75 Hadijatou Mani Koraou (n 74 above) 2.

76 Manzo (n 2 above) 395.

77 T Nhenga-Chakarisa 'Who does the law seek to protect and from what? The application of international law on child labour in an African context' (2010) 10 African Human Rights Law Journal 164.

78 United Nations. 'Convention on the Rights of the Child' (1989) art 32 http:// www.ohchr.org/EN/Professionallnterest/Pages/CRC.aspx (accessed 3 March 2015). 
According to Bass, although the CRC 'uses privileged and idealised Western concepts of childhood', it fails to acknowledge the cultural differences that influence the lives of children, especially in developing countries. ${ }^{79}$ Bass's opinion is shared by Morganti, who criticises the legislative measures that recently have been adopted against child labour, as they do not take into account local perceptions of childhood. ${ }^{80}$ As a consequence, governments of countries where children are exploited can argue that the CRC refers to a Westernised model of protection, while regional social practices in countries such as Togo, Ghana, and Benin are core parts of the national culture. As a result, the international protection of human rights cannot efficiently intervene with their sanctions and due to ignorance about regional practices, the international mechanisms cannot provide the intended universal protection. Consequently, 81

[t]he provision of child welfare programmes and services has been largely left to foreign and local non-governmental organisations [as in case of Ghanaian NGOs against trokosi] - and UN agencies such as UNICEF, Save the Children, and Plan International, instead of well-financed public, child welfare agencies, staffed by professionally-trained social workers.

The protection of exploited children is further specified and complemented by the conventions of the ILO. Since 1919, the ILO has been the most pivotal forum in the campaign for human conditions of employment, including efforts against child labour. With the aim of protecting employees, it adopted ten conventions between 1919 and 1965 concerning the minimum age for admission to employment and work, and it subsequently decided to consolidate all these conventions into the Minimum Age Convention 138 of 1973 (Convention 138). The efforts of the CRC to protect children from exploitation were earlier foreshadowes by the ILO Forced Labour Convention 29 of 1930 (Convention 29) that had as its focus labour exploitation. However, it is disappointing to note that, even though decision makers in the ILO had in 1930 agreed to 'suppress the use of forced or compulsory labour in all its forms within the shortest possible period', children are exploited in most of the countries of the world. ${ }^{82}$ Furthermore, it provided an open-ended definition of forced labour, without listing specific prohibitions. Article 2 defines forced labour as 'all work or service which is exacted from any person under the menace of any penalty and for which the said person has not offered himself voluntarily'. ${ }^{83}$ Despite having outlawed a wide range

79 L Bass Child labour in sub-Saharan Africa (2004)19.

80 Morganti (n 15 above) 84.

81 Soussou \& Yogtiba (n 9 above) 1221.

82 ILO Forced Labour Convention (1930) http://www.ilo.org/dyn/normlex/en/f?p= NORMLEXPUB:12100:0::NO::p12100_instrument_id:312174 (accessed 15 September 2016) art 1.

83 D Frey \& C Fletcher 'Protocol to ILO Convention No 29: A step forward for international labour standards. Human rights brief' 2 http://hrbrief.org/2015/05/ protocol-to-ilo-convention-no-29-a-step-forward-for-international-labourstandards/ (accessed 15 September 2016). 
of exploitations, Convention 29 has not been able to provide an environment for state agencies in which ILO principles are efficiently implemented in order to protect the victims. Frey and Fletcher agree that $^{84}$

despite the broad range of coverage offered by [this convention], there was a feeling that additional measures were needed to eradicate modern forms of forced labour by addressing gaps in implementing the conventions.

In the case of efforts by the ILO to cover the implementation gaps in the field of forced labour, the UN showed a consistent interest reconciliation. Because of the contribution of the International Labour Office and the ILO Committee on Forced Labour, the General Conference of the International Labour Conference adopted a Protocol to Convention 29 on 11 June 2014. Being neither a new convention nor a soft law recommendation, the Protocol has acknowledged human rights violations, including the role of human trafficking in providing large numbers of victims to different forms of forced labour. Therefore, it states that 'the measures referred to in this Protocol shall include specific action against trafficking in persons for the purposes of forced or compulsory labour'. ${ }^{85}$ Following a victimcentred approach, articles 3 and 4 require 'access to appropriate and effective remedies' to ensure that states do not penalise victims for 'their involvement in unlawful activities which they have been compelled to commit as a direct consequence of being subjected to forced or compulsory labour'. ${ }^{86}$ Frey and Fletcher believe that ' $[\mathrm{t}] \mathrm{he}$ Protocol has the potential to help countries focus on eradicating both challenges, simultaneously and with equal vigour' ${ }^{87}$ Furthermore, the Protocol was born after having reviewed the gaps of Convention 29 and it puts meaningful emphasis on prevention, identification and the treatment of the root causes of slavery. Despite promising a basis for the international protection against forced labour via its Protocol, success depends, firstly, on the ratification and, secondly, on the implementation.

Since the adoption of Convention 29, the ILO has been focusing on other dimensions of labour that presumably influence the exploitation of children. For instance, Mavunga, quoting Myers, claims that '[Convention 138] was adopted not only to cater for the needs of children but also as a response to the fear that the participation of children in work undermines adult jobs and incomes' ${ }^{88}$ According to

\footnotetext{
84 As above.

85 Frey \& Fletcher (n 83 above) 3.

86 Frey \& Fletcher 4.

87 As above.

88 R Mavunga 'A critical assessment of the Minimum Age Convention 138 and the Worst Forms of Child Labour Convention 182 of 1999' (2013) 16 Potchefstroom Electronic Law Journal 126.
} 
article 1 of Convention 138, member states are encouraged to 89

undertake to pursue national policy designed to ensure the effective abolition of child labour and to raise progressively the minimum age for admission to work to a level being consistent with the fullest physical and mental development of young persons.

However, the Convention does not specify what kind of practices should be targeted by national legislation. Since it is left to member states to define child labour on their own, the difference in the definitions can have a negative impact on the universal implementation of the Convention. Only article 3 provides states with a guideline regarding the minimum age of employment of a child, stating that '[t]he minimum age ... shall not be less than the age of completion of compulsory schooling and, in any case, shall not be less than 15 years'. ${ }^{90}$ Unfortunately, the persistence of domestic servitude and ritual slavery that affects children and teenagers in large numbers in some African countries illustrates that the implementation of the Convention leaves much room for improvement.

Furthermore, the Convention does not impose an obligation on member states to take any specific measures beyond drafting legislation to ensure the effective abolition of child labour. Due to these shortcomings, the author agrees with Mavunga that Convention 138 does not provide much guidance to member states as to what ought to be the nature of the national fight against child labour. Mavunga confirms the point that efforts directed at abolishing human rights violations such as domestic servitude and ritual slavery can only be efficient if they target poverty and some of its effects, such as absenteeism from school, with social policies. ${ }^{91}$ It is only by targeting socio-economic challenges that child labour can be abolished. If parents find proper employment and children are educated under humane conditions, families will not find themselves economically trapped and will not feel themselves compelled to send their children away to work for the benefit of the family.

ILO Convention 182 generally prohibits the worst forms of child labour by suggesting that children are victims of economic and sexual exploitation and in such cases suffer from the loss of personal freedom and freedom of movement. Convention 182 expresses the reality of contemporary slavery. In article 3, it specifies the worst forms of child labour as 92

89 ILO No 138 Minimum Age Convention (1973) http://www.ilo.org/dyn/normlex/ en/f?p=NORMLEXPUB:12100:0::NO::P12100_INSTRUMENT_ID:312283 (accessed 6 July 2016) art 1.

90 Art 3 ILO No 138 Minimum Age Convention (n 89 above).

91 Mavunga (n 88 above) 127.

92 Art 3 ILO Convention 182 The Worst Forms of Child Labour (1999) http://www. ilo.org/dyn/normlex/en/f?p=NORMLEXPUB:12100:0::NO:12100:P12100_ILO_CO DE:C182 (accessed 15 September 2016). 
all forms of slavery, or practices similar to slavery, such as the sale and trafficking of children, debt bondage, serfdom and forced or compulsory labour, including forced or compulsory recruitment of children for use in armed conflict.

There are critical views regarding Convention 182 such as that it concentrates on core criminal actions, yet the ILO has very little competence in criminal justice systems. ${ }^{93}$ However, Mavunga defends the ILO's efforts, claiming that the fact that the ILO deals with the tripartite relationship between the employer, the government and the employee shows that its concerns are predominantly in the area of labour. ${ }^{94}$ For instance, Convention 182 does not only demand national authorities to $95^{\prime}$

prevent the engagement of children in the worst forms of child labour; provide the necessary and appropriate direct assistance for the removal of children from the worst forms of child labour and for their rehabilitation and social integration; and ensure access to free basic education, and, wherever possible and appropriate, vocational training, for all children removed from the worst forms of child labour; [but it also orders that they should] integrate provision and application of penal sanctions or, as appropriate, other sanctions that would contribute to the prevention of the further extension of child labour.

The UN offered their ready-made universal, Westernised concept of children's rights protection to African countries which these countries adapted to their local contexts. As a result, the Organisation of the African Union (OAU) became the first continent-wide organisation to adopt a regional human rights instrument with respect to the rights of children, specifically adapted to the conditions of societies in the region. It prides itself as respecting children's rights from an 'African' perspective. Therefore, the preservation of African cultural norms would actually presuppose stricter and more efficient national systems of protection against child labour and not the survival of systemic, illegal practices of exploitation.

The fact that the African Children's Charter can be regarded as the 'African' version of the CRC means that it imposes certain 'responsibilities' on children towards their family, society, the state and other legally-recognised communities and the international community. ${ }^{96}$ Here, the OAU took into consideration the peculiar importance of children not only in the family but also in society. It emphasised the fact that children not only exist in society in the sense of being persons who should be protected but, apart from that, they are also core members of the community. Therefore, apart from their rights, they have certain responsibilities, first and foremost towards

93 D Smolin 'Strategic choices in the international campaign against child labour' (2000) 22 Human Rights Quarterly 973.

94 Mavunga (n 88 above) 158.

95 Art 7 ILO Convention (n 92 above).

96 Art 31 African Charter on the Rights and Welfare of the Child (1990) http://www. au.int/en/sites/default/files/Charter_En_African_Charter_on_the_Rights_and_Wle fare_of_the_Child_AddisAbaba_July1990.pdf (accessed 25 March 2015). 
their parents and to society. In other words, African societies 'do not view the individual as an autonomous being possessed of rights above and prior to society'. ${ }^{97}$ Consequently, today African children are still considered as having the responsibility to work for the cohesion and sustenance of their families, to put their physical and intellectual abilities at the service of their communities and to preserve cultural values in their relations with others. ${ }^{98}$ This is used by fishermen, merchants and parents who send their children away with strangers as an argument to make children work without a salary and under inhuman conditions. However, the special importance of belonging to a community and respect towards the family can never be the justification of exploitation in an environment where international and regional human rights instruments outlaw such practices. As SlothNielsen and Mezmur argue, 99

culture should not be relied on as a basis for diminishing protected rights. Where positive, culture should be harnessed for the advancement of children's rights. But when it appears that children are disadvantaged or disproportionately burdened by a cultural practice, the benefits of the cultural practice and the harm of the human rights violation must be weighed against each other.

However, article 15 of the African Children's Charter protects the responsibility to work only by stating that '[e]very child shall be protected from all forms of economic exploitation and from performing any work that is likely to be hazardous or to interfere with the child's physical, mental, spiritual, moral, or social development'. ${ }^{100}$

The cohabitation of the rights and responsibilities of children in Africa was confirmed by the decision of the African Committee of Experts on the Rights and Welfare of the Child (African Children's Committee) in the case of the Centre for Human Rights, University of Pretoria and La Rencontre Africaine pour la Défense des Droits de I'Homme $v$ Senegal in 2014. The African Children's Committee protected the rights of the talibés (young boys aged four to 12 years) who allegedly suffered forced begging by their instructors (marabouts). The children had daily targets to meet and if they could not reach these targets, it resulted in their beating and punishment at the hands of the marabouts. ${ }^{101}$ These children were victims of contemporary slavery since their lives were controlled by their instructors: They were forced to work under violent conditions, and

97 Nhenga-Chakarisa (n 77 above) 169.

98 As above.

99 Sloth-Nielsen \& Mezmur (n 27 above) 350.

100 Art 15 African Children's Charter.

101 Centre for Human Rights, University of Pretoria and La Rencontre Africaine pour la Défense des Droits de l'Homme v Senegal (2014) African Committee of Experts on the Rights and Welfare of the Child https://www.crin.org/en/library/legaldatabase/centre-human-rights-university-pretoria-and-la-rencontre-africaine-pourla (accessed 29 April 2017). 
slept in overcrowded rooms or outside, with little or no access to clean water or sanitation, leaving them susceptible to contracting various diseases. ${ }^{102}$

As a result, the African Children's Committee claimed that ${ }^{103}$

although the Senegalese government was not directly responsible for the abuse of the talibés and that it had in fact taken legislative measures against begging and child trafficking, these measures alone were insufficient to protect the rights of the talibés.

The exploitation of the talibés resulted in breaches of several articles of the African Children's Charter, namely, breaches of article 4 (the best interests of the child); article 5 (the right to survival and development); article 11 (the right to education); article 14 (the right to health and health services); article 15 (relating to child labour); article 29 (prohibition of sale, trafficking and abduction of children); article 16 (protection against child abuse and torture); and article 21 (protection against harmful and social practices). ${ }^{104}$

The judgment in this case illustrates that regional and national institutions of human rights protection should be aware that domestic servitude, ritual slavery and other forms of contemporary slavery occur in certain African countries. This is despite several international human rights instruments prohibiting slavery, in general, and different forms of contemporary slavery that are in force in these countries. However, the author is convinced that the implementation of the international, regional and national instruments for protection against vidomegon, trokosi and vudusi will be difficult until there is a single and universallyadopted definition of child labour, together with the introduction of international protection against contemporary slavery. At present, the ILO Conventions approach child labour in terms of a minimum age of employment. The CRC views child labour not in terms of the activity, but in terms of the effect of the activity on the child concerned. The CRC deems any form of labour unacceptable if it is detrimental to the development of the child, regardless of whether it takes place in a workplace or at home. ${ }^{105}$ On the other hand, the African Children's Charter merely prohibits the economic exploitation of a child and any work that has the same elements as those prohibited under the CRC. However, the controversial relationship between the CRC and the African Children's Charter, without the acknowledgment of African social specificities and the implementation gaps among ILO Conventions, suggests a lack of consistency both in the definition of child labour under international law and in the implementation of efforts to combat the practice.

102 As above.

103 As above.

104 As above.

105 Nhenga-Chakarisa (n 77 above) 177. 
Thus, the international community should dedicate a legal instrument to the definition of contemporary forms of labour and sexual exploitation affecting millions of children worldwide. It has to respect the local interpretation of the role of the child in society, and it also has to oblige state parties to introduce measures for raising awareness regarding contemporary slavery and for integrating it as a crime into the criminal codes of countries, in order that the perpetrators may be held responsible for human rights violations. Only once the international community can expand its activities in the fight against slavery beyond the role of the UN Special Rapporteur on Contemporary Forms of Slavery, and state parties are obliged to make their own national efforts dedicated to abolishing contemporary slavery, will it be possible for victims to access support beyond that of local NGOs in order to gain protection of their rights.

\section{Conclusion}

When children are exploited, they are forced to work under inhuman conditions without receiving a salary, proper nutrition and accommodation. They suffer physical and sexual abuse. In order to better understand the push and pull factors of the current forms of child labour and labour exploitation, the article discussed a number of examples of continued exploitation in West Africa, such as ritual slavery in Ghana and Togo through the practices of trokosi and vudusi, and domestic servitude in Benin with an analysis of vidomegon. Arguing that these practices involve a series of human rights violations and exploitation, the article regards them as forms of contemporary slavery. These illegal practices still flourish in West Africa, despite the fact that they are outlawed by national authorities and international human rights instruments. This is because the implementation of national and regional efforts to abolish domestic servitude and ritual slavery is weakly monitored.

The current international law on contemporary slavery remains ineffectual, as it fails to understand diverse forms of human rights violations, emphasising only the practice of the denial of property rights, mental and/or physical abuse and control. The definition of contemporary slavery should be extended to include a condition that relates to the forced and arbitrary abuse of a victim's labour. This connects slavery with forced labour, child labour, domestic servitude, ritual slavery, sexual slavery and debt bondage. The autocratic disposal of the labour force distinguishes practices belonging to contemporary slavery from other forms of exploitation, such as organ trafficking and prostitution. Due to the lack of a unanimouslyaccepted notion of contemporary slavery in international law, the article urged activists/the UN/AU to adopt an international human rights convention solely dedicated to the modern forms of sexual and labour exploitation. However, the argument of the article did not neglect to acknowledge the significance of the ECOWAS Community 
Court judgment in the case of Hajidatou Mani $v$ Niger and the expanded notion provided by the Supplementary Convention on the Abolition of Slavery, the Slave Trade and Institutions and Practices Similar to Slavery of the fight against slavery. These have both contributed to a better understanding of how slavery-like practices currently affect millions of people and how international law should regard these infringements in order to abolish them.

The conceptual argument of calling for a new human rights instrument dedicated uniquely to contemporary slavery provided the background for an introduction to the forms of child exploitation in three West African countries. The article then examined children's rights with special attention to the different perspective of protection provided by the international and the African human rights instruments. Here, the distinct perception of childhood and the role of the child in society result in conflict among international and local organisations fighting against ritual slavery and domestic servitude. Therefore, current forms of child exploitation, such as vidomegon, trokosi and vudusi, can only be eliminated definitively if the international and regional human rights protection systems, in the framework of the $\mathrm{UN}$ and the $\mathrm{AU}$, respect and acknowledge both the rights and the responsibilities of the African child.

Clearly, the agenda for human rights protection both internationally and in Africa should be to harmonise inconsistencies and reconcile international and regional norms. However, the article does not argue that granting children more robust rights would lead to the elimination of domestic servitude and ritual slavery in West Africa. As was seen in the example of vidomegon, parents send their children away from home, sometimes into a neighbouring country, as they do not see any alternative to earning a living. To them this still seems a better idea than sending their children to school. Therefore, international and regional efforts have to target not only the harmonisation of rights on the level of human rights instruments, but they also have to alleviate economic problems and increase the levels of education. This should be the priority of local and regional social policies, so that illegal practices do not present advantageous opportunities for families to send their children away to work. 